\title{
Cutaneous metastatic pancreatic adenocarcinoma
}

\author{
Sarah Nasser 다, ${ }^{1}$ Abraham Husseini (10), ${ }^{1}$ Shirisha Pasula, ${ }^{2}$ Avnish Sandhu ${ }^{2}$
}

${ }^{1}$ Internal Medicine and Pediatrics, Wayne State University School of Medicine, Detroit, Michigan, USA ${ }^{2}$ Infectious Disease, Wayne State University School of Medicine, Detroit, Michigan, USA

\section{Correspondence to \\ Sarah Nasser:}

ft9300@wayne.edu

Accepted 24 September 2021

\section{DESCRIPTION}

A 71-year-old man presented with a painful left-sided axillary rash which had been progressing for the past month. He had visited multiple outside facilities, where he was treated for shingles with a 5-day course of acyclovir and an aggressive pain regimen. However, he had no improvement in symptoms hence he presented to our institution. He had a medical history of pancreatic adenocarcinoma at the ampulla of Vater, diagnosed in 2015, and underwent Whipple's surgery followed by chemoradiation achieving complete remission. $\mathrm{He}$ continued to follow-up with his oncologist for routine surveillance and was in remission for approximately 4 years.

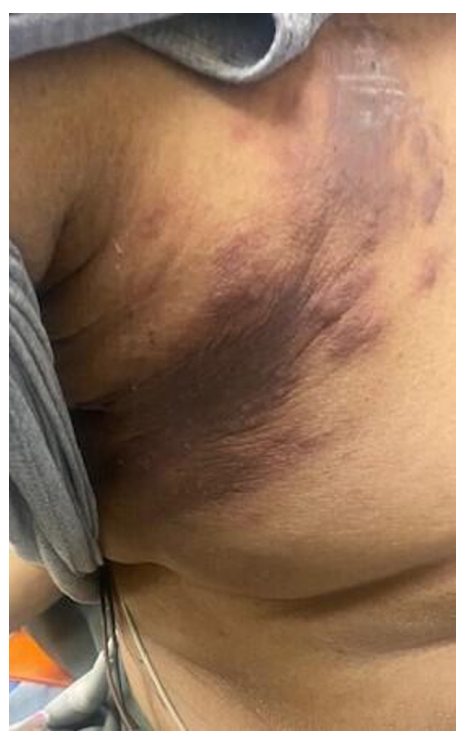

Figure 1 Initial skin lesion.

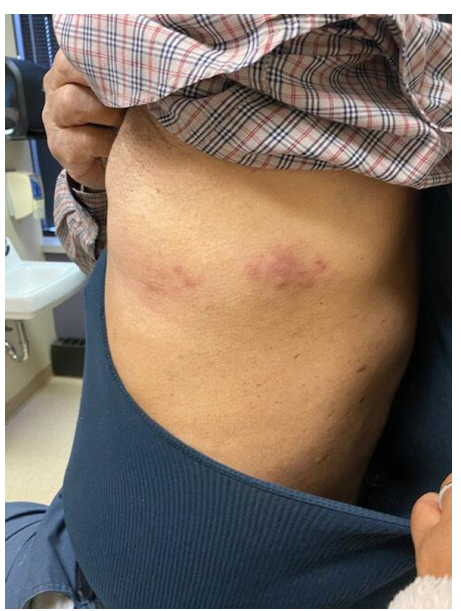

Figure 2 Skin lesion on presentation to our hospital.

\section{Patient's perspective}

When my dad was first diagnosed with pancreatic cancer, we thought it was something related to his gallbladder. He was diagnosed with jaundice and his gallbladder failed and was removed. The jaundice came back, so the doctors did more looking and ran further tests and that's how he got the diagnosis of pancreatic cancer. Treatment was started including surgery, radiation and chemotherapy and then he was in remission for 4 years. Unfortunately, it came back.

When we found out the cancer came back, it was during COVID, and everything was in lock down. It started as a rash under his arm, he had a lot of discomfort and couldn't get in to see his team of doctors because of COVID so we did tele-health. They couldn't understand what it was, so they gave him medicine to help with pain. But it kept hurting and got worse, so we took him to an urgent clinic, and they said it looked like shingles. They started treating him for shingles and it still didn't get any better. The rash kept getting worse. We did another telehealth visit, but they just continued the same treatment. To add on to everything going on, insurance was also giving us a hard time with my dad's tele-health visits.

More time went by, and the rash got worse with no improvement. Then he had an episode at home where the pain got so bad under and through his arm area, that he had balance issues and fell. We rushed him to the hospital where he was admitted. They did a lot of tests and looked at the rash. They decided to do a biopsy and found out that it was the same cancer that came back and spread. As soon as we found out the cancer came back, his systems started shutting down. There was an infection in his blood, and we were told there was a spot located in his lung area and his breathing started to decline. He developed pneumonia and was intubated and placed on the vent. He continued to decline and passed away.

From my perspective, I wonder if it wasn't COVID times, would the cancer had been caught earlier. Due to the shutdown, it was hard to be physically seen at the doctor's office. I also think to myself how didn't I connect the dots that it could have been the previous cancer that returned. My dad was in remission for so long that I too believed that it could have been shingles. Due to the fact that I got more than one doctor's diagnosis that it was shingles the recurrence of cancer was not my first thought. We all should've thought about cancer when he wasn't responding to the shingles treatment. I would suggest and love for all doctors to always go back to investigate recurrent cancer first before coming up with other diagnoses. Time is of essence! I also feel that because of it being COVID and the confusion surrounding those times, a lot of people with pre-existing issues got left behind. The focus was solely on COVID.

I want to thank the doctors and everyone on his team for everything they did do during these difficult times. 
On physical examination, we noted a T2 dermatomal rash with hyperpigmented indurated plaque with few satellite papules with no vesicular or open lesions (figure 1). Initial rash at onset is illustrated in figure 2. Our differential diagnoses included atypical shingles or malignancy. Dermatology was consulted for skin biopsy, which revealed moderately differentiated adenocarcinoma from pancreatobiliary origin. Further oncological work up was performed with CT abdomen/pelvis and MRCP, which also revealed signs consistent for recurrent pancreatic tumour with metastasis and gastric outlet obstruction. Serum oncological markers were also found to be significantly elevated, with CA $19-9$ at $13189 \mathrm{U} / \mathrm{mL}$ and CA 125 at $591.4 \mathrm{U} / \mathrm{mL}$, supporting the diagnosis. Unfortunately, the patient had a prolonged hospital course with multiple complications and the patient passed away.

\section{Learning points}

- Recurrence of pancreatic adenocarcinoma should be considered in patients presenting with cutaneous manifestation.

- Cutaneous metastatic pancreatic cancer is rare, constituting $<10 \%$ of all cases.
Cutaneous metastasis from pancreatic cancer is rare; the most predominant manifestation is metastasis at the umbilicus. Non-umbilical cutaneous metastatic cases have been observed, however are infrequent. ${ }^{1}$ Non-umbilical cutaneous metastasis may represent dissemination of malignancy signifying poor overall survival. $^{2}$ Considering the diagnosis of metastasis and prompt recognition is imperative to reducing delayed treatment.

Contributors SN planned, conducted and reported the work. AH, SP and AS identified and managed the case.

Funding The authors have not declared a specific grant for this research from any funding agency in the public, commercial or not-for-profit sectors.

Competing interests None declared.

Patient consent for publication Parental/guardian consent obtained.

Provenance and peer review Not commissioned; externally peer reviewed.

\section{ORCID iDs}

Sarah Nasser http://orcid.org/0000-0001-5960-5774

Abraham Husseini http://orcid.org/0000-0002-0352-1800

\section{REFERENCES}

1 Zhou H-Y, Wang X-B, Gao F, et al. Cutaneous metastasis from pancreatic cancer: a case report and systematic review of the literature. Oncol Lett 2014;8:2654-60.

2 Ramachandran P, Boyapati L, Joseph G. Scalp metastasis as the first presentation of an underlying aggressive pancreatic cancer. I Investig Med High Impact Case Rep 2020:8:232470962093166

Copyright 2021 BMJ Publishing Group. All rights reserved. For permission to reuse any of this content visit https://www.bmj.com/company/products-services/rights-and-licensing/permissions/

BMJ Case Report Fellows may re-use this article for personal use and teaching without any further permission.

Become a Fellow of BMJ Case Reports today and you can:

- Submit as many cases as you like

- Enjoy fast sympathetic peer review and rapid publication of accepted articles

- Access all the published articles

- Re-use any of the published material for personal use and teaching without further permission

Customer Service

If you have any further queries about your subscription, please contact our customer services team on +44 (0) 2071111105 or via email at support@bmj.com.

Visit casereports.bmj.com for more articles like this and to become a Fellow 